\title{
Soil Physical Quality in Agricultural Systems on the Cerrado of Piauí State, Brazil
}

\author{
THIAGO R. SCHOSSLER ${ }^{1}$, ROBÉLIO L. MARCHÃ ${ }^{2}$, ISIS L. DOS SANTOS ${ }^{3}$, DJAVAN \\ P. SANTOS ${ }^{4}$, JÚLIO CÉSAR A. NÓBREGA ${ }^{5}$ and GLENIO G. SANTOS ${ }^{4}$
}

\author{
${ }^{1}$ Programa de Pós-Graduação em Ciência do Solo, Universidade Federal Rural de Pernambuco, \\ Rua Dom Manoel de Medeiros, s/n, Dois Irmãos, 52171-900 Recife, PE, Brazil \\ ${ }^{2}$ Empresa Brasileira de Pesquisa Agropecuária/EMBRAPA, Embrapa Cerrados, \\ Rodovia BR-020, Km 18, 73310-970 Planaltina, DF, Brazil \\ ${ }^{3}$ Programa de Pós-Graduação em Agronomia, Faculdade de Agronomia e Medicina \\ Veterinária, Universidade de Brasília, 70297-400 Brasília, DF, Brazil \\ ${ }^{4}$ Programa de Pós-Graduação em Agronomia (Solo e Água), Escola de Agronomia, Universidade \\ Federal de Goiás, Avenida Esperança, s/n, 74690-900 Goiânia, GO, Brazil \\ ${ }^{5}$ Programa de Pós-Graduação em Solos e Qualidade de Ecossistemas, Centro de Ciências Agrárias, Ambientais e Biológicas, \\ Universidade Federal do Recôncavo da Bahia, Rua Rui Barbosa, 710, 44380-000 Cruz das Almas, BA, Brazil
}

Manuscript received on July 5, 2018; accepted for publication on August 22, 2018

\begin{abstract}
Soil quality is essential for maintaining the sustainability of agro-ecosystems and ecosystem services provided by this natural resource. The present study aimed to assess the physical quality of soil through the characterization of the physical properties in grain production systems in the Southwest region of Piauí State, Brazil. The study was carried out in the Cerrado region of Piaú in four cities in areas of expansion of the agricultural frontier of the state: Baixa Grande do Ribeiro, Sebastião Leal, Uruçuí and Bom Jesus. Soil samples were collected in April 2012, in areas of grain production under conventional and no-tillage systems. Adjacent areas with native vegetation were also sampled as reference. Bulk density, effective saturation, hydraulic conductivity, penetration resistance, porosity and aggregation were measured. Regardless of the type of soil management used, agricultural systems degrade soil physical quality. No-tillage showed higher bulk density, penetration resistance and aggregation, with lower total porosity, macroporosity and hydraulic conductivity. The physical quality of soil in the agricultural areas of the Cerrado region of Piauí was dependent on the soil texture, while silt, clay and organic matter were determinant for soil aggregation, mechanical resistance, total porosity and microporosity.
\end{abstract}

Key words: sustainable intensification, no-tillage, porosity, aggregation, Oxisols.

\section{INTRODUCTION}

No-till farming (NT) was proposed by the Brazilian government to comply with the country's voluntary commitment to reduce greenhouse gas

Correspondence to: Robélio Leandro Marchão

E-mail: robelio.marchao@embrapa.br
(GHG) emissions by $36 \%$. The goal is to increase the area planted under no-till by eight million hectares until 2020 (Mapa 2012). This goal, which is part of the Low Carbon Agriculture program ( $\mathrm{ABC}$ in portuguese), is one of the top Brazilian public policies, aimed to mitigate $\mathrm{GHG}$ emissions 
and increase carbon stocks in agricultural soils (Corbeels et al. 2016).

No-tillage, as well as crop rotation, mulchtill system and no plowing is considered as conservation agricultural practices that can bring several benefits, especially greater efficiency in the control of water erosion (Panachuki et al. 2011, Islam and Reeder 2014). The formation of stable aggregates in water contributes to the improvement of soil physical quality, restoring its porosity, affecting water infiltration processes and contributing to groundwater recharge (Vicente et al. 2012).

The Southwest of Piauí is inserted in the region called "Matopiba" because it is made up of the states of Maranhão, Tocantins, Piauí and Bahia and is the main agricultural frontier of the Cerrado biome. This region extends over an area of 12 million hectares, of which $12 \%$ is currently destined for grain production (Conab 2016). Over the last three decades, there has been a significant increase in agricultural activities in this Cerrado region, with increasing replacement of native vegetation by cultivated areas, especially for food, fiber and energy production (Santos et al. 2016).

Since the site of the present study is a region of expansion of the agricultural frontier, few studies for assessment of the impact of soil management on the conversion of natural areas into agricultural areas were carried out. In the Matopiba region, light-textured soils account for $20 \%$ of the territory and are mainly constituted by Neossolos, Latossolos and Argissolos (Donagemma et al. 2016). The incorporation of these areas is usually done by conventional soil management, with the purpose of incorporating residues and soil correctives for later conversion to no-tillage. In an attempt to reduce the original porosity detected in native areas, inappropriate agricultural practices, particularly under conventional tillage, have led to soil degradation (Marchão et al. 2008, Sena et al. 2017). Although chemicals are used in the beginning of the process to correct soil acidity, not all agricultural practices are adopted to prepare the soil for long-term no-till farming. Also, significant investments were made in large, high-performance agricultural machinery, which not always ensure an appropriate agricultural management and observation of soil conservation practices (Borghi et al. 2016). In general, soil cultivation is minimized, without crop rotation or succession planting, and soil preparation, although superficial, is a common practice in the region, leading to soil physical degradation, as a result of changes in physical, chemical and biological properties of these soils caused by excessive soil disturbance and lack of effective mulch cover (Berisso et al. 2012).

In a study conducted in this region, Pragana et al. (2012) reported that replacement of native vegetation by monoculture-based farming systems causes abrupt ecological changes, often marked by degradation of ecosystem services and soil quality. In the Cerrado of Piauí, few studies addressed the effect of soil management systems on soil properties. In a study conducted in the Uruçui-PI region, in a medium-textured Oxisol, Fontenele et al. (2009) reported that no-tillage did not improve soil aggregation compared to conventional tillage, and the authors attributed this result to the short time period that has elapsed since the implementation of the system.

Since this region is an area of expansion of the agricultural frontier, the characterization of the impact of conversion of native areas into agricultural systems on soil physical quality is still incipient, and further studies are needed. Our hypothesis is that the no tillage promotes better soil physical quality even recently after the conversion of conventional tillage. The importance of soil physical quality and the relationship between soi physical attributes is also emphasized in this paper. Finally, this study aimed to assess soil physical quality by characterizing the soil physical properties in no-till, by comparing its evolution 
from the conventional and reference Cerrado native vegetation areas in four municipalities of the Southwest region of Piauí.

\section{MATERIALS AND METHODS}

The study was carried out in the Southwest region of the state of Piauí in grain-producing farms located in four municipalities of the Cerrado (Figure 1): Baixa

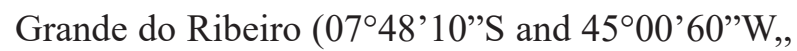
altitude $600 \mathrm{~m})$, Sebastião Leal (07³9'14'S and 4402'37'W, altitude $450 \mathrm{~m}$ ); Uruçuí (08¹4'07'S

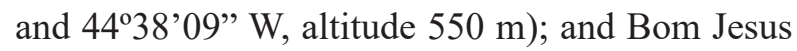
(09 $10^{\prime} 35^{\prime \prime} \mathrm{S}$ and 4450'36”'W, altitude $600 \mathrm{~m}$ ).

The climate of the region is Aw (tropical savanna climate), according to Köppen climate classification, with predominance of rainy season between October and April and annual average precipitation of $1200 \mathrm{~mm}$. The Matopiba region is mostly formed by light-texture soils and in all sampled areas the soil profiles were classified as Latossolo Amarelo Distrófico típico (Santos et al. 2013) or Ferralsols (WRB 2015). The original Cerrado vegetation was composed of remnant semi-deciduous seasonal forest (Pragana et al. 2012). Analysis of the soil granulometric distribution of the areas was performed according to Claessen (1997), and the results are shown in Table I. The selection of areas and farms aimed to contemplate areas with different soil textures. Table II shows history data of the selected farms.
The sampling was performed in April 2012, in areas of grain production under conventional tillage (CT) and no-tillage (NT) and in remnants of native Cerrado vegetation (NV), used as reference. The sampling points in each of the selected farms were defined after demarcation, with the aid of GPS equipment, of a one-hectare (100 m x $100 \mathrm{~m})$ plot containing 25 points equidistant from each other in a regular mesh. Subsequently, five points were drawn among the twenty-five demarcated points, to compose the five repetitions of each area. A trench was opened at each point, and between the sowing lines four subsamples were collected, at 0-0.10, 0.10-0.20 and 0.20-0.30 m depths. The soil samples were collected with a stainless steel coresoil with an approximate volume of $95 \mathrm{~cm}^{3}$. The deformed samples were packed in plastic bags. In native vegetation areas, sampling was carried out in three randomly demarcated trenches, at least 25 meters apart from each other, and with a minimum distance of 50 meters from the edges.

Bulk density (BD in $\mathrm{Mg} \mathrm{m}^{-3}$ ) was calculated by the core-soil method according to Equation 1, described in the manual of soil analysis methods (Donagemma et al. 2011).

$$
\mathrm{BD}=\frac{\mathrm{M}}{\mathrm{V}}
$$

Where: $\mathrm{BD}$ - is bulk density $\left(\mathrm{Mg} \mathrm{m}^{-3}\right) ; \mathrm{M}$ - is the mass of the dried sample at $105^{\circ} \mathrm{C}(\mathrm{g})(\mathrm{Mg}) ; \mathrm{V}$ - is the core-soil volume $\left(\mathrm{m}^{3}\right)$.

TABLE I

Results of the particle size analysis and soil organic matter contents, averages of the 0-0.3 $\mathrm{m}$ layer in the sampled areas located in the Southwest Piauí State, Brazil.

\begin{tabular}{ccccccc}
\hline \multirow{2}{*}{ Municipalities } & Clay & Silt & Fine Sand & Coarse Sand & Total Sand & Soil Organic Matter \\
\cline { 2 - 6 } & & & & $\mathbf{g ~ k g ~}^{-1}$ & & \\
\hline Baixa Grande do Ribeiro & 618 & 125 & 70 & 187 & 257 & 27.1 \\
Bom Jesus & 216 & 33 & 108 & 643 & 751 & 11.1 \\
Sebastião Leal & 319 & 67 & 145 & 470 & 615 & 12.8 \\
Uruçuí & 187 & 24 & 147 & 642 & 789 & 10.3 \\
\hline
\end{tabular}


Effective saturation (ES, in $\mathrm{m}^{3} \mathrm{~m}^{-3}$ ) was determined according to Marchão et al. (2007) and Santos et al. (2011) through Equation 2.

$\mathrm{ES}=\theta_{\mathrm{s}}-\theta_{15,198.75}$

where: $\theta_{\mathrm{s}}$ is soil moisture at saturation; $\theta_{15,198.75}$ is soil moisture measured in the potential $-15,198.75$ $\mathrm{hPa}$.

Hydraulic Saturated Conductivity (Ksl, in $\mathrm{mm} \mathrm{h}^{-1}$ ) was obtained in laboratory according to Donagema et al. (2011), which is based on the rate at which water flows through soil. The soil samples were saturated for 24 hours in a core-soil, with the inflow of fluids maintained at a constant head. Darcy's law was used in the measurement of hydraulic conductivity. From the four subsamples, three core-soil were selected whose Ksl values were considered homogeneous and closer to the average for use in the determination of the other physical properties.

Determination of penetration resistance (PR) was performed with impact penetrometer, with a 4 $\mathrm{kg}$ mass plunger (standard), calculated according to Equation 3 (Stolf 1991).

$\mathrm{PR}=\frac{\mathrm{Mg}+\mathrm{mg}+\left[\frac{\mathrm{M}}{\mathrm{M}+\mathrm{m}} *\left(\frac{\mathrm{Mg} * \mathrm{~h}}{\mathrm{x}}\right)\right]}{\mathrm{A}}$

where: PR - penetration resistance, $\mathrm{kgf} \mathrm{cm}^{-2} ; \mathrm{M}$ mass of the apparatus without plunger $(3.2 \mathrm{~kg})(\mathrm{mg}$ $=3.2 \mathrm{kgf}) ; \mathrm{h}$ - plunger drop height $(40 \mathrm{~cm}) ; \mathrm{x}$ penetration of the apparatus stem, $\mathrm{cm}^{-1}$ impact, and A - cone area, $1.29 \mathrm{~cm}^{2}$. PR values were multiplied by factor 0.098 to obtain PR in MPa. Measurements were randomly made at six points around the trenches. Six readings were taken to obtain an average value per point, totaling 18 replicates per area, as described by Marchão et al. (2007).

Penetration resistance was measured concomitantly in same day, at the same soil moisture content, in each of the areas, for the two soil management systems (CT and NT) and native vegetation, to allow comparison between the soil management systems.

The average PR values were classified according to the Soil Survey Staff (1993), which proposed the following PR classes of soils: extremely low $(<0.01 \mathrm{MPa})$; very low $(0.01$ 0.1 MPa); low (0.1-1.0 MPa); moderate (1.0-2.0 $\mathrm{MPa})$; high (2.0-4.0 $\mathrm{MPa})$; very high (4.0 - 8.0 $\mathrm{MPa})$ and extremely high (> 8.0 MPa).

Based on the saturation of the sample, total porosity (TP, in $\mathrm{m}^{3} \mathrm{~m}^{-3}$ ) was determined according to Donagemma et al. (2011), calculated using the equation below (4):

$\mathrm{TP}=\frac{\mathrm{V}_{\mathrm{SAT}}}{\mathrm{V}}$

Where: $\mathrm{V}_{\text {sat }}$ - is the volume of water contained in the pores of saturated soil obtained by the difference between the weight core-saturated soil and core-dry soil at $\mathrm{g} 105^{\circ} \mathrm{C}\left(\mathrm{m}^{3}\right), \mathrm{V}$ is the soil volume obtained from the core-soil volume ( $\pi \mathrm{r} 2 \mathrm{~h}$ ), expressed in $\mathrm{m}^{3}$.

Soil macroporosity (MaP; in $\mathrm{m}^{3} \mathrm{~m}^{-3}$ ) was computed as the difference between total soil water content at saturation (Rogowski 1971, Silva and Azevedo 2002) (PT, $\left.\mathrm{m}^{3} \mathrm{~m}^{-3}\right)$, considered as the saturated water gravimetric content, and volumetric water content after equilibrium has been reached with soil water potential of $-60 \mathrm{hPa}$ (Equation 3) were obtained by centrifuge method (Freitas Jr. and Silva 1984) after previous saturation of the samples through the procedure described by Silva and Azevedo (2002). This potential was regarded as the upper limit of microporosity (MiP).

$\mathrm{MaP}=\mathrm{PT}-\theta_{60}$

Microporosity (MiP; $\mathrm{m}^{3} \mathrm{~m}^{-3}$ ) was considered as the gravimetric content at $-60 \mathrm{hPa}$.

Soil aggregate characterization was determined with wet sieving apparatus (Yoder 1936), as described in the Manual of Methods of Soil Analysis of Embrapa (Donagemma et al. 2011), in 
which the quantity and size distribution of water stable aggregates are calculated, and are related to the aggregates that did not disintegrate by sieving.

The calculation of the percentage of aggregates retained in each sieve was expressed in the following order: $>2.00 \mathrm{~mm}$ (AG1); $2.00-1.00 \mathrm{~mm}$ (AG2); 1.00-0.50mm (AG3); 0.50-0.25mm (AG4) and $<0.25$ (AG5), through Equation 6.

$$
A G=100 \frac{A}{B}
$$

Where: AG - is the percentage of aggregates in each sieve; A - weight of the aggregate retained in each sieve at $105^{\circ} \mathrm{C}$; B - weight of the sample dried at $105{ }^{\circ} \mathrm{C}$. The aggregate content $<0.25 \mathrm{~mm}$ was obtained by subtracting the total weight of the aggregates retained in the sieves of the total weight of the dried sample at $105{ }^{\circ} \mathrm{C}$. Aggregates smaller than $<0.25 \mathrm{~mm}$ (AG5) were obtained by the difference between the sum of the aggregates retained in the sieves and the total mass of the dried sample at $105^{\circ} \mathrm{C}$.

Macroaggregation (MaA) and microaggregation $(\mathrm{MiA})$ were also calculated by equations 7 and 8 , respectively:

$$
M a A=100 \frac{A G>0.25}{\Sigma_{A G}}
$$

Where: MaA - is macroaggregation in \%; $\mathrm{AG}>0.25$ is the sum of the aggregates larger than $0.25 \mathrm{~mm}$; $\Sigma_{\mathrm{AG}}$ - is the sum of the total aggregates of the sample.

$$
\mathrm{MiA}=100 \frac{\mathrm{AG}>0.25}{\Sigma_{\mathrm{AG}}}
$$

Where: MiA - is microaggregation in \%; $\mathrm{AG}>0.25$ - is the number of aggregates smaller than 0.25 $\mathrm{mm} ; \Sigma_{\mathrm{AG}}-$ is the sum of the total aggregates of the sample.
The distribution of aggregates per diameter class, according to Donagemma et al. (2011) was expressed by the geometric mean diameter (GMD) according to equation (9).

$\mathrm{GMD}=\exp \frac{\sum_{\mathrm{i}=1}^{\mathrm{n}} \mathrm{n} \cdot \log \mathrm{Xi}}{\sum_{\mathrm{i}=1}^{\mathrm{n}} \mathrm{Wi}}$

Where: $\mathrm{Xi}$ - is the mean diameter of the classes $(\mathrm{mm}) ; \mathrm{Wi}$ - is the ratio of each class to the total; $\mathrm{N}$ is the percentage of stable aggregates in each class.

The data were organized according to the management system and depth, and descriptive statistics was performed using box-plot graphs to present the measures of central tendency, dispersion, discrepant and extreme values.

In order to verify the relationships between soil physical properties in each one of the sampled areas, conditioned to soil texture and organic matter, a principal component analysis (PCA) was performed in a matrix of 36 lines (three areas/ systems, four farms and three soil layers) by 10 columns (physical properties). PCA was performed using the CANOCO statistical program, version 4.5 (Food and Agriculture Organization of the United Nations, New York), where soil texture and organic matter data were plotted as explanatory variables (canonical correlation) not included in the analysis as a dependent variable in the statistical model.

\section{RESULTS AND DISCUSSION}

Figures 2, 3 and 4 show the box-plot graphs constructed for each soil management system by depth, where arithmetic, median, maximum, minimum, general data dispersion and atypical (spurious) samples are observed.

The areas under no-tillage (NT) had bulk density (BD) values ranging from 1.02 and $1.75 \mathrm{mg}$ $\mathrm{m}^{-3}$, with means of $1.43,1.52$ and $1.52 \mathrm{Mg} \mathrm{m}^{-3} \mathrm{~m}$ for 0-0.1, 0.1-0.2 and 0.2-0.3 m layers, respectively (Figure 2). The areas under conventional tillage (CT) ranged BD between 0.90 and $1.68 \mathrm{Mg} \mathrm{m}^{-3}$, 


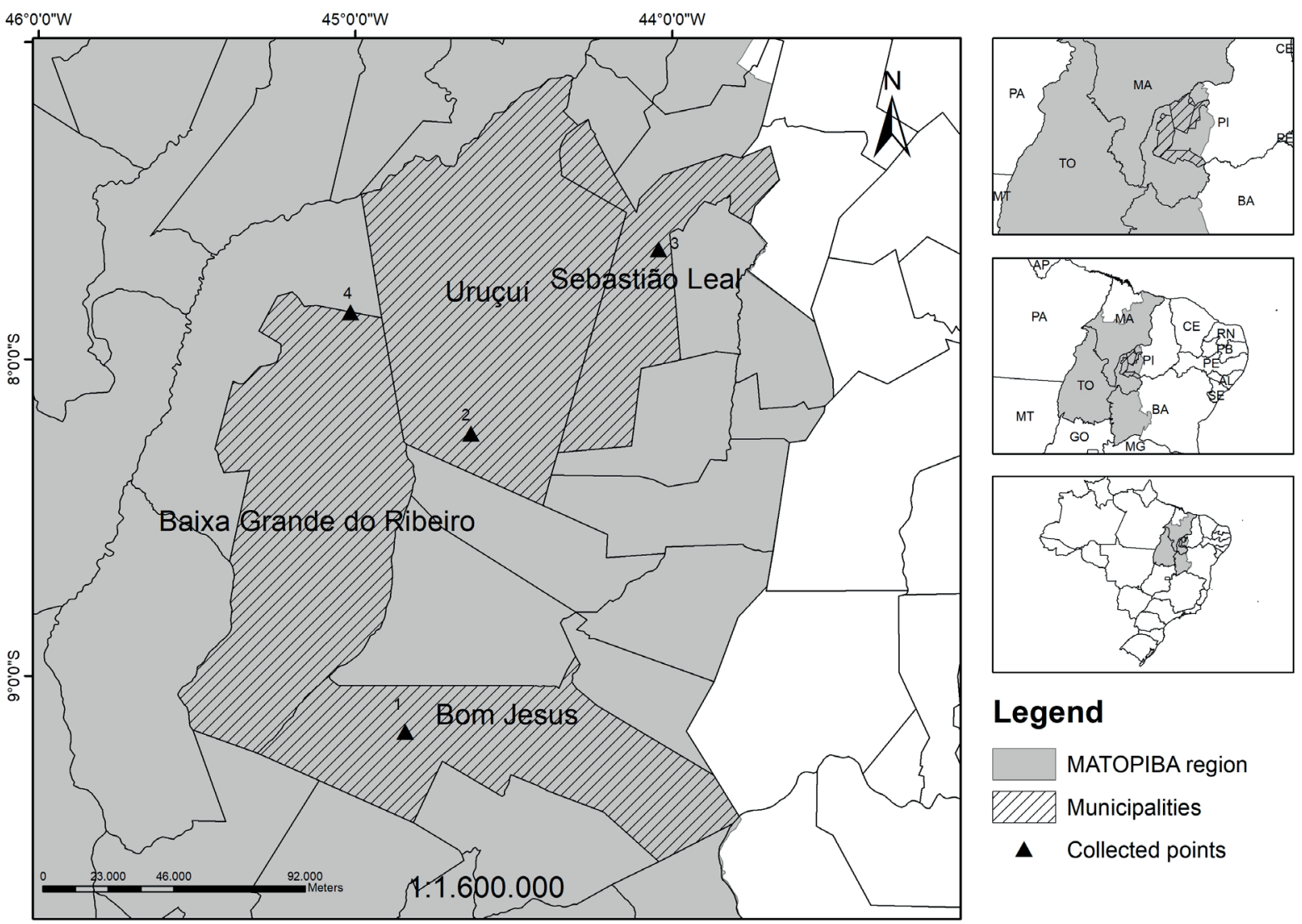

Figure 1 - Municipalities and points indicating farms location in the study in the Southwest region of the Piauí State.

with means of $1.27,1.40$ and $1.43 \mathrm{Mg} \mathrm{m}^{-3}$ for $0-0.1$, 0.1-0.2 and 0.2-0.3 m layers, respectively. No-till showed higher bulk density (BD) at all the depths investigated when compared to conventional tillage, whose values were closer to the values found in the areas under native vegetation (NV), with means ranging between 1.22 to $1.36 \mathrm{Mg} \mathrm{m}^{-3}$. The higher bulk density in no-tillage is explained by the absence of plowing associated with traffic of machines and implements, especially in moist soil conditions (Souza et al. 2015, Sá et al. 2016). The average values for bulk density in no-tillage are within the range of 1.36 to 1.72 reported by Silva et al. (2014) also in the Cerrado of Piauí, while the values obtained for native vegetation and notillage are lower than that obtained by the referred authors. These differences are related to the higher sand content in the soils studied by the referred authors (higher than $75 \%$ ), while in the present study some soils had higher clay content, e.g. in Baixa Grande do Ribeiro, with $275 \mathrm{~g} \mathrm{~kg}^{-1}$ of sand (Table I), which may have contributed to the lower average value obtained in the present study. Most of the variation in bulk density is due to differences in total pore volume (Llanillo et al. 2006). Beutler et al. (2012) also reported higher bulk density in notillage compared to conventional tillage. The values obtained for no-tillage are higher than the value considered critical to proper plant development proposed by Arshad et al. (1996), which is 1.40 $\mathrm{Mg} \mathrm{m}^{-3}$. In a study conducted in Cerrado soils, Sá et al. (2016) obtained as a limiting value for bulk density of $1.33 \mathrm{Mg} \mathrm{m}^{-3}$, but only for very clayey soils.

In all soil layers, no-tillage system showed average effective saturation (ES) values of 0.16 to 
$\mathrm{BD}(0-0.1 \mathrm{~m})$

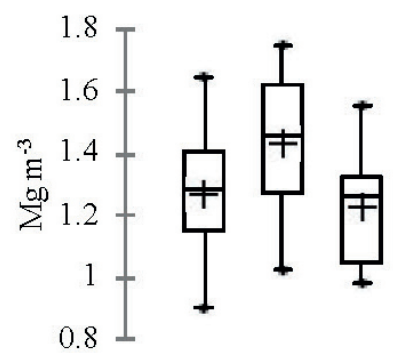

ES $(0-0.1 \mathrm{~m})$

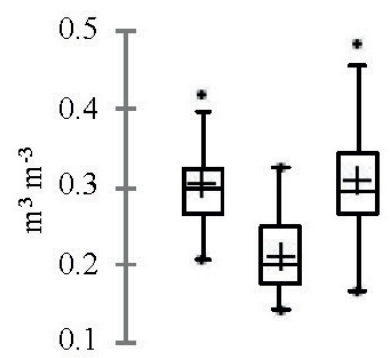

$\operatorname{Ksl}(0-0.1 \mathrm{~m})$

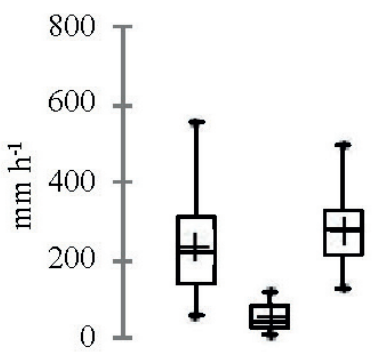

PR (0-0.1 m)

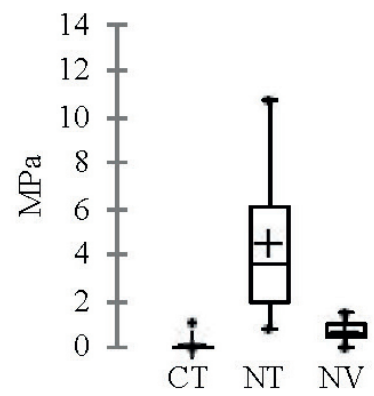

$\mathrm{BD}(0.1-0.2 \mathrm{~m})$

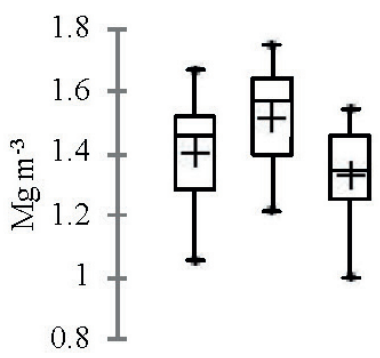

ES $(0.1-0.2 \mathrm{~m})$

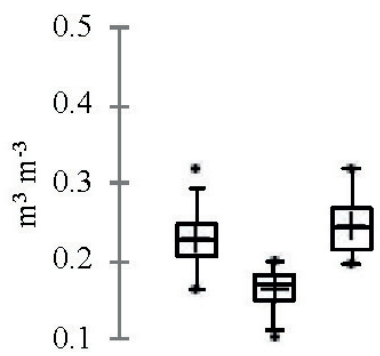

$\mathrm{Ksl}(0.1-0.2 \mathrm{~m})$

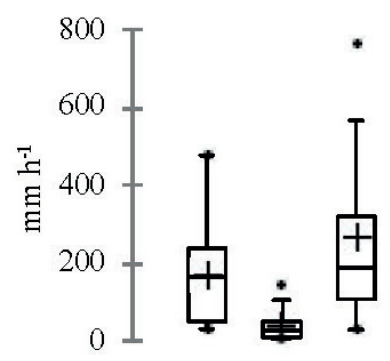

PR (0.1-0.2 m)

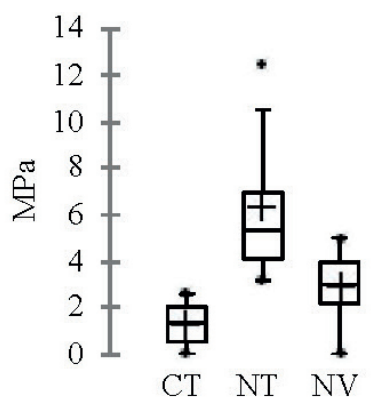

$\mathrm{BD}(0.2-0.3 \mathrm{~m})$

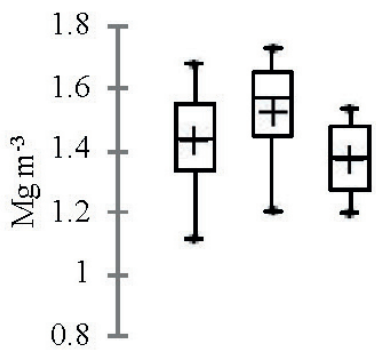

ES $(0.2-0.3 \mathrm{~m})$

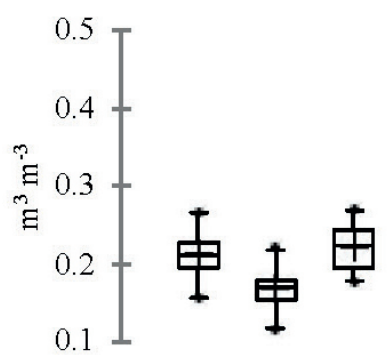

$\mathrm{Ksl}(0.2-0.3 \mathrm{~m})$

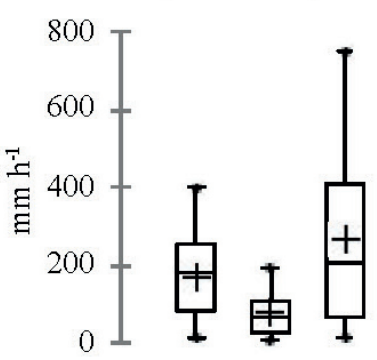

PR (0.2-0.3 m)

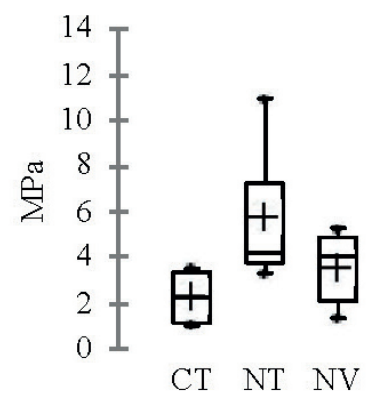

Figure 2 - Averages with their respective confidence intervals for bulk density (BD), effective saturation (ES), laboratory hydraulic conductivity (Ksl) and soil penetration resistance (PR) in conventional tillage (CT), no-tillage (NT) and native vegetation (NV) at three depths. 
$0.21 \mathrm{~m}^{3} \mathrm{~m}^{-3}$, between the depths, lower than those obtained in conventional tillage, which ranged between 0.21 and $0.30 \mathrm{~m}^{3} \mathrm{~m}^{-3}$, as shown in Figure 2. The higher ES content suggests that conventional tillage, due to its greater macroporosity (MaA), has higher water retention capacity between saturation and the permanent withering point (Castro et al. 2010). Santos et al. (2011) found similar saturation values between 0.12 and 0.32 , in clayey Oxisol under integrated croplivestock system in the Cerrado of Goiás, Brazil. However, although the ES content in conventional tillage system is similar to the values found in native vegetation at all soil layers, the effect of mechanical management practices that involve the use of farm implements to break up and smoothing out soil surface and subsoilers cannot effectively control compaction, requiring periodic mechanical interventions, as reported by Chamen et al. (2015).

In no-tillage system, hydraulic conductivity values (Ksl) were lower than $75 \mathrm{~mm} \mathrm{~h}^{-1}$, i.e., lower than the value of $163 \mathrm{~mm} \mathrm{~h}^{-1}$ obtained in conventional tillage (Figure 2). Conventional tillage was the system with Ksl value most similar to that of native vegetation in all soil layers. Such data corroborates the findings of Silva et al. (2005) and Kamimura et al. (2009) who also reported a higher Ksl value under conventional tillage compared to no-tillage. Soil mobilization may have increased water-borne macropores raising Ksl, although this effect is temporary (Soracco et al. 2012). In notillage, one of the causes of Ksl reduction may be the effect if soil compaction, which reduces the number of water-conducting pores, and is consistent with the present study and also with Stone et al. (2002). These authors reported that compaction reduced the number of water-conducting pores, i.e., the pores with larger diameter. According to Drescher et al. (2016), Ksl is one of the most sensitive soil properties for assessing the duration of mechanical decompaction.
Soil penetration resistance (PR) has always been measured concomitantly with soil moisture, in each area, for both soil management systems (CT and NT) and native vegetation. Since there was no significant change in water content between the areas, the differences were attributed to the effect of the soil management systems. No-tillage showed higher PR values (between 4.52 and 6.36 MPa in the layers) at all depths when compared to conventional tillage (Figure 2), and the highest value (6.36 MPa) was found at the 0.1-0.2 m depth, i.e. classified as a very high level of penetration resistance according to the Soil Survey Staff (1993). The lower mean values obtained with conventional tillage (between 0.14 and $2.25 \mathrm{MPa}$ ) are attributed to the effect of soil plowing for the incorporation of residues and in the process of planting, which is classified as low to moderate PR, according to Soil Survey Staff (1993). However, the values obtained for this layer suggests that the so-called "plow pan" layer tends to remain even after implementation of no-tillage, possibly due to an unsuccessful no-tillage stage or even failure to comply with all the requirements of this practice, such as deep rooted crops, subsurface correction, crop rotation, and mulch cover (Berisso et al. 2012).

The values of penetration resistance (PR) in no-tillage at all soil depths, in native vegetation at depths greater than $0.1 \mathrm{~m}$, and in conventional tillage at a depth of 0.2-0.3 m were greater than 2 $\mathrm{MPa}$, reported by Tormena et al. (1998) as critical to proper plant development. In the Cerrado of Piauí, Barbosa et al. (2016) also found PR values higher than $2 \mathrm{MPa}$ at the 0.2-0.3 $\mathrm{m}$ depths and similar values for native vegetation. The higher resistance penetration in native vegetation at depths greater than $0.1 \mathrm{~m}$ indicates that this value does not prevent root development. According to Tavares Filho et al. (2001), PR values described in the literature as critical to root development (1 to $3.5 \mathrm{MPa}$ ), maybe did not restrain root development of maize in no- 
tillage and conventional tillage systems, though it affected root morphology.

Total porosity (TP) results showed an inverse behavior of BD under native vegetation and conventional tillage, with higher averages compared to no-tillage (Figure 3). In soil management systems, TP distribution was more asymmetric at a depth of 0.1-0.2 m. At this depth, data is mostly concentrated in the second quartile, indicating a tendency to lower TP values for both soil management systems compared to native vegetation where the interquartile was more symmetrical. According to the referred data, the higher values for bulk density in no-tillage are detected in the first stage of the process, in conventional tillage, and is explained by the cumulative effect of subsurface compaction, called "plow pan" or "tillage pan" (Cortez et al. 2011).

Conventional tillage had total porosity values of $0.42,0.34$ and $0.32 \mathrm{~m}^{3} \mathrm{~m}^{-3}$ at $0-0.1,0.1-0.2$ and 0.2-0.3 m layers, respectively, and these results were similar to those obtained for native vegetation at all soil layers. Due to soil disturbance caused by constant plowing, conventional tillage promotes increase in TP, but such increase cannot be maintained after plowing, as reported by Bortoluzzi et al. (2008) and Chamen et al. (2015). Thus, over the years, with the implementation of no-tillage system, the greater availability of organic matter, the absence of soil disturbance and the use of crop rotation is expected to improve soil physical properties. Marcolan and Anghinoni (2006) found higher TP in no-tillage
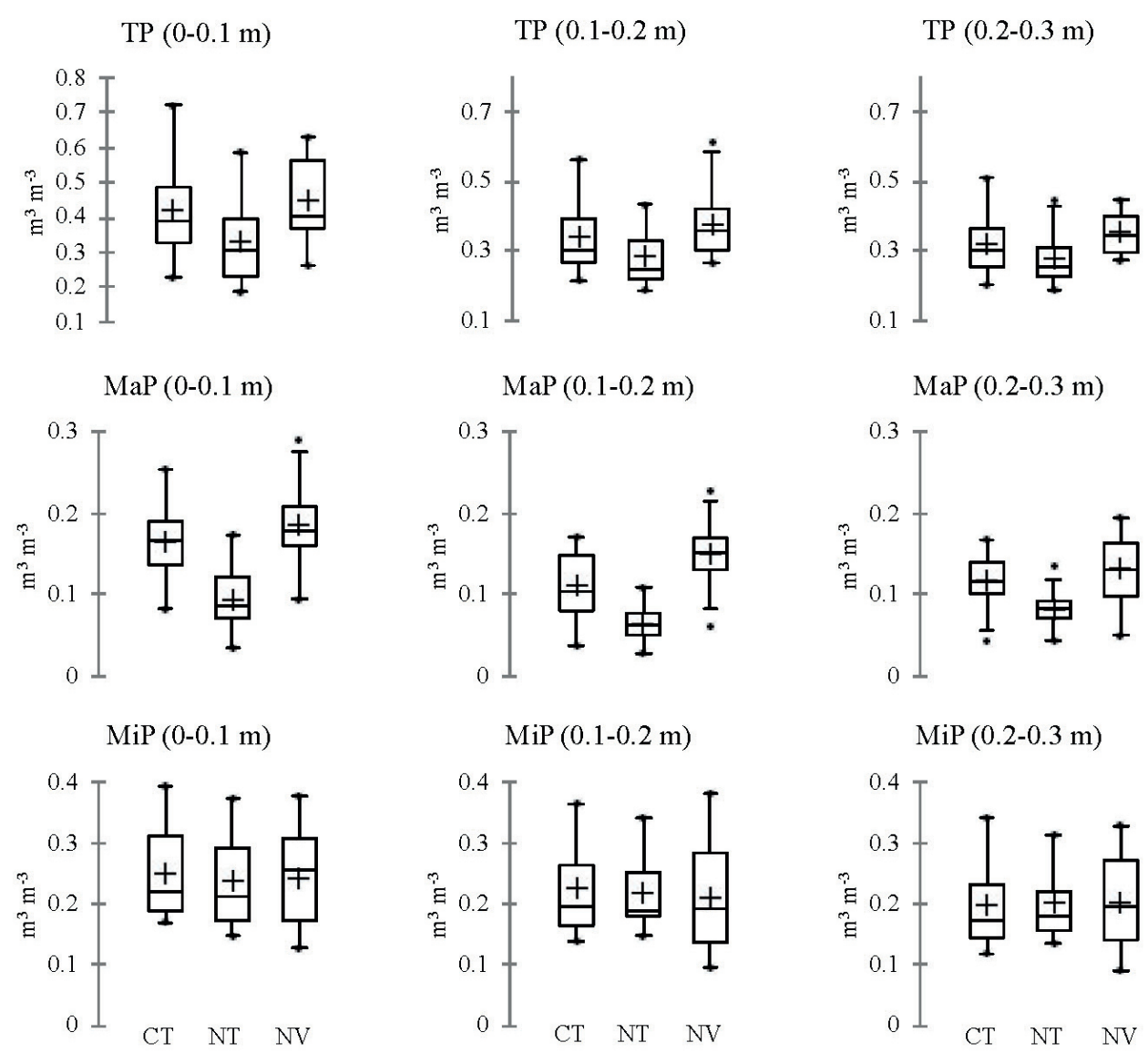

Figure 3 - Averages with their respective confidence intervals for total porosity (PT), macroporosity (MaP) end microporosity (MiP) in conventional tillage (CT), no-tillage (NT) and native vegetation (NV) at three depths. 
after eight and twelve years of implementation of the practice compared to a period of four years of no-tillage practice. In a study conducted in the Cerrado of Piauí, Pragana et al. (2012) obtained a lower value of total porosity in no-tillage compared to native vegetation, and attributed these results to the heavy traffic of farm implements, which reduces aggregate stability, reduces macroporosity $(\mathrm{MaP})$, increases microporosity (MiP), resulting in a denser soil matrix. The traffic of agricultural machinery and implements in conventional tillage leads to soil compaction and impacts soil structure, reducing total porosity, especially at deeper soil layers (Barbosa et al. 2016). Possibly, as a result of these soil disturbance practices in conventional tillage, soil compaction tends to persist even after the implementation of no-tillage farming in a region where crop rotation cannot be performed and mulch cover is scarce because rainy seasons are shorter than in other agricultural regions of the Cerrado.

The behavior of macroporosity (MaP) was similar to that of total porosity, with conventional tillage showing means similar to those obtained in native vegetation and mean values higher than those of no-tillage farming (Figure 3). At 0.1$0.2 \mathrm{~m}$ and 0.2-0.3 $\mathrm{m}$ depths no-tillage showed MaP values of 0.06 and $0.08 \mathrm{~m}^{3} \mathrm{~m}^{-3}$, respectively, which are lower than the values obtained in conventional tillage, namely, $0.16,0.11,0.12 \mathrm{~m}^{3} \mathrm{~m}^{-3}$. On the other hand, no-tillage showed average values below the limit considered critical for mediumtexture soils, of $0.10 \mathrm{~m}^{3} \mathrm{~m}^{-3}$, which may affect plant development. Possibly, the higher MaP levels reported in conventional tillage are associated to the recent plowing of soil performed in this soil management system (Table II). These results are consistent with those obtained by Tormena et al. (2002) who reported increases in TP and MaP in conventional tillage and minimum cultivation compared to no-tillage, and attributed these results to the use of rake and scarifiers. Andreotti et al. (2010) obtained a linear correlation between soil physical properties (MaP, MiP, PT and BD) and soybean yield and concluded that $\mathrm{MaP}$ at the $0-0.10$ $\mathrm{m}$ layer was the best indicator of physical quality regarding soybean yield in no-tillage, in Cerrado soils. Although conventional tillage exhibits a higher $\mathrm{MaP}$ in the first stage of the process, over time soil particles are expected to rearrange themselves to form a more compact structure due to the traffic of agricultural machines and implements. This natural rearrangement caused by frequent soil tillage may impair the future implementation of no-tillage, generating compacted soil layers (Figueiredo et al. 2008).

Microporosity (MiP) showed equal means in the two soil management systems and native vegetation, ranging from 0.20 to $0.25 \mathrm{~m}^{3} \mathrm{~m}^{-3}$ (Figure 3). Araújo et al. (2010) also did not find differences in MiP values between soil management systems in the Cerrado of Piauí. These results corroborate the findings of Bertol et al. (2004), who inferred that this variable is more resistant to the effects of soil management systems compared to other soil physical properties such as MaP, TP and BD.

On the other hand, in no-tillage, 77.01 to $79.44 \%$ of macroaggregates $(\mathrm{MaA})$ were obtained at the assessed layers, values higher than 72.84 to $76.43 \%$ found in conventional tillage (Figure 4), which corroborates that soil aggregation capacity is higher in no-tillage. However, the values obtained in the management systems are lower than those of native vegetation. The higher MaA in no-tillage may be related to the higher amount of organic matter produced under this management system compared to conventional tillage that involves intensive soil disturbance, and hence organic matter oxidation (Castro Filho et al. 1998, Costa Junior et al. 2011). These data indicate that regardless of nonobservation of all no-tillage practice requirements, absence of soil disturbance alone contributes to increase soil aggregation. 
TABLE II

History of the different soil management systems sampled in the municipalities of the Southwest Piauí State, Brazil.

\begin{tabular}{|c|c|c|}
\hline Municipalities & Soil management system & Description \\
\hline \multirow{2}{*}{$\begin{array}{l}\text { Baixa Grande } \\
\text { do Ribeiro }\end{array}$} & Conventional Tillage & $\begin{array}{l}\text { Converted in } 1990 \text {. Rice cultivation under conventional tillage until } \\
1994 / 95 \text { (year of lime application) and rice cultivation, remaining in } \\
\text { fallow until } 1999 \text {. In the } 2000 / 01 \text { to } 2009 / 10 \text { crop, conventional tillage and } \\
\text { soybean cultivation, followed by soybean/pearl millet succession. }\end{array}$ \\
\hline & No-Tillage & $\begin{array}{l}\text { Converted in 1990. Four years conducted with soybean in conventional } \\
\text { tillage. Fallow from } 1995 \text { to } 2006 \text {. Lime application in } 2006 / 2007 \text { crop } \\
\text { season and cultivation with soybean/pearl millet succession since this crop } \\
\text { season. }\end{array}$ \\
\hline \multirow[b]{2}{*}{ Sebastião Leal } & Conventional Tillage & $\begin{array}{l}\text { Converted in 2010. Conventional tillage with application of liming } \\
\text { and pearl millet cultivation in the 2010/11 crop. Soybean cultivation in } \\
\text { conventional tillage in the } 2011 / 2012 \text { crop season. }\end{array}$ \\
\hline & No-Tillage & $\begin{array}{l}\text { Converted in } 1997 \text {, started under soybean conventional tillage with lime } \\
\text { application. From } 1998 / 1999 \text { to } 1999 / 2000 \text {, soybean cultivation. In the } \\
2000 / 2001 \text { crop season pearl millet was cultivated. From } 2001 / 2002 \text { to } \\
2007 / 2008 \text { soybean cultivation, followed by cotton in } 2008 / 2009 \text {, maize in } \\
\text { the } 2009 / 2010 \text { and soybean to } 2011 / 2012 \text {. }\end{array}$ \\
\hline \multirow[b]{2}{*}{ Uruçuí } & Conventional Tillage & $\begin{array}{l}\text { Converted in } 2009 \text {, started under conventional tillage with lime application } \\
\text { and rice cultivation in the } 2009 / 2010 \text { crop season. Pearl millet in } 2010 / 2011 \\
\text { crop season. Soybean cultivation in the } 2011 / 2012 \text {. }\end{array}$ \\
\hline & No-Tillage & $\begin{array}{l}\text { Converted in } 1999 \text {, started under rice conventional tillage with lime } \\
\text { application and rice cultivation in the } 2000 / 2001 \text { and } 2001 / 2002 \text { crop } \\
\text { seasons, soybean cultivation from } 2002 / 2003 \text { to } 2006 / 2007 \text { crop seasons. } \\
\text { From } 2007 / 2008 \text { to } 2008 / 2009 \text { soybean/pearl millet succession was } \\
\text { cultivated. Maize in the } 2010 / 2011 \text { crop season and soybean/cowpea } \\
\text { succession in } 2011 / 2012 \text { crop season. }\end{array}$ \\
\hline \multirow[b]{2}{*}{ Bom Jesus } & Conventional Tillage & $\begin{array}{c}\text { Converted in 2009, started with cowpea under conventional tillage and } \\
\text { lime application for cowpea cultivation from 2010/2011 to 2011/2012 crop } \\
\text { season. }\end{array}$ \\
\hline & No-Tillage & $\begin{array}{c}\text { Converted in 2002, started soybean cultivated under conventional } \\
\text { tillage until the 2005/2006 crop season. Pearl millet from 2006/2007 to } \\
\text { 2008/2009. Soybean/pearl millet succession from 2009/2010 to 2011/2012 } \\
\text { crop season. }\end{array}$ \\
\hline
\end{tabular}

Microaggregation (MiA) showed an inverse behavior to that of macroaggregation in soil under $\mathrm{CT}$, exhibiting higher levels of MiA. However, in both systems these values were lower than those of native vegetation (Figure 4). Bilibio et al. (2010) comparing the CT with NT, verified a reduction of the geometric mean diameter (GMD) of aggregates with subsurface compaction in conservation systems, whereas in conventional systems there was a decrease in the surface layer, due to the constant soil revolving, which breaks the aggregates into smaller units.

Analysis of the relationships between soil physical properties conditioned to the effect of soil texture and organic matter can be seen in Figure 5. Used as additional (canonical) variables, texture and organic matter explained approximately $20 \%$ of the total variability of data. The physical properties that contributed most to principal component 1 were Ksl and ES, contrasting with $\mathrm{MaA}$ and MiA, which are inversely proportional and contribute more to principal component 2 . Clay, silt and organic matter $(\mathrm{OM})$ showed greater impact on soil physical properties GMD, MiP, RP and TP, while soil coarser fractions (fine and coarse sand) were more related to soil bulk density. These results demonstrate that the higher the clay-silt fraction, the greater GMD, MiP, RP and PT values, 


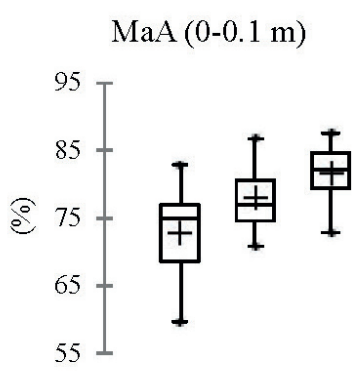

$\operatorname{MiA}(0-0.1 \mathrm{~m})$

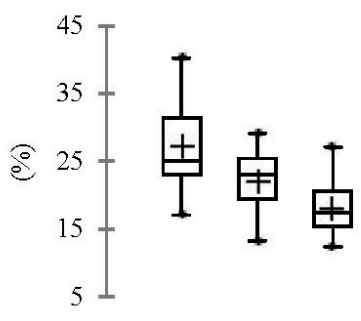

$\operatorname{GMD}(0-0.1 \mathrm{~m})$

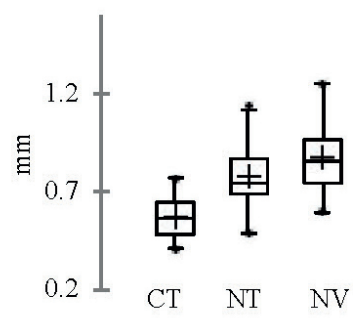

$\operatorname{MaA}(0.1-0.2 \mathrm{~m})$

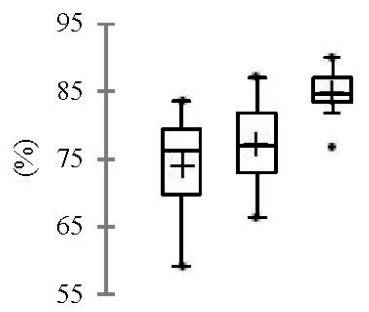

$\operatorname{MiA}(0.1-0.2 \mathrm{~m})$

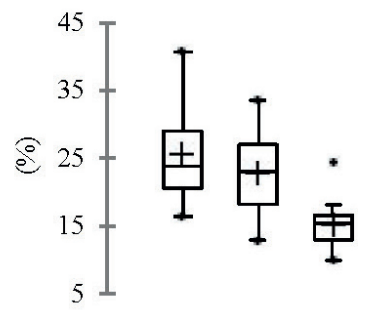

$\operatorname{GMD}(0.1-0.2 \mathrm{~m})$

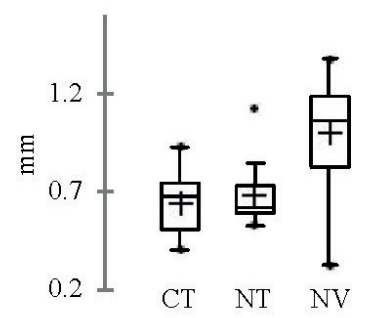

$\operatorname{MaA}(0.2-0.3 \mathrm{~m})$

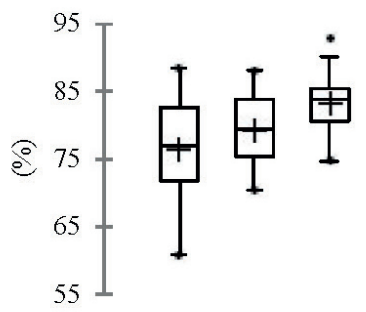

$\operatorname{MiA}(0.2-0.3 \mathrm{~m})$

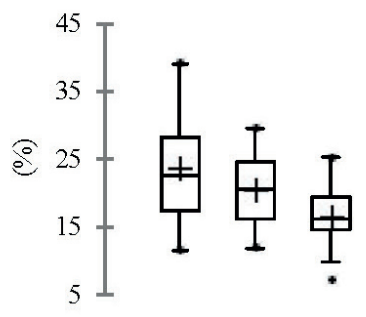

$\operatorname{GMD}(0.2-0.3 \mathrm{~m})$

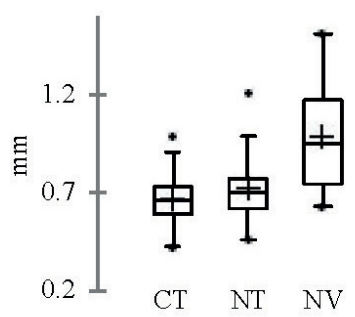

Figure 4 - Averages with their respective confidence intervals for macroaggregates (MaA), microaggregates $(\mathrm{MaP})$ and geometric mean diameter (GMD) in conventional tillage (CT), no-tillage $(\mathrm{NT})$ and native vegetation $(\mathrm{NV})$ at three depths.

while higher sand content is related to areas with higher soil density.

Principal component analysis (PCA) indicates that native vegetation tends to present higher MaP, ES and Ksl values, represented by the cloud point group associated with these variables. On the other hand, areas under conventional tillage were associated with higher values of bulk density (BD) and MiA, reinforcing the hypothesis that higher $\mathrm{BD}$ values in no-tillage system are detected as soon as this system is implemented and remain high afterwards. Pragana et al. (2012) also found that native vegetation tends to relate with $\mathrm{MaP}$ and $\mathrm{TP}$, while no-tillage was associated with $\mathrm{BD}$, in the Cerrado of Piauí. Such data corroborates that the current grain production systems in the Cerrado of Piauí result in degradation of soil physical quality compared to the native vegetation of this region. However, although no-tillage farming has higher $\mathrm{BD}$ and RP and lower TP, MaP and Ksl, this system apparently tends to favor a better soil physical quality, as it promotes better soil aggregation in the long run. Finally, the implementation of no-tillage system, with observation of all its requirements, may contribute to faster improvement of soil physical quality in the Piauí Cerrado region.

\section{CONCLUSIONS}

Soil management in agricultural areas of grain production in the Cerrado of Piauí affects soil 


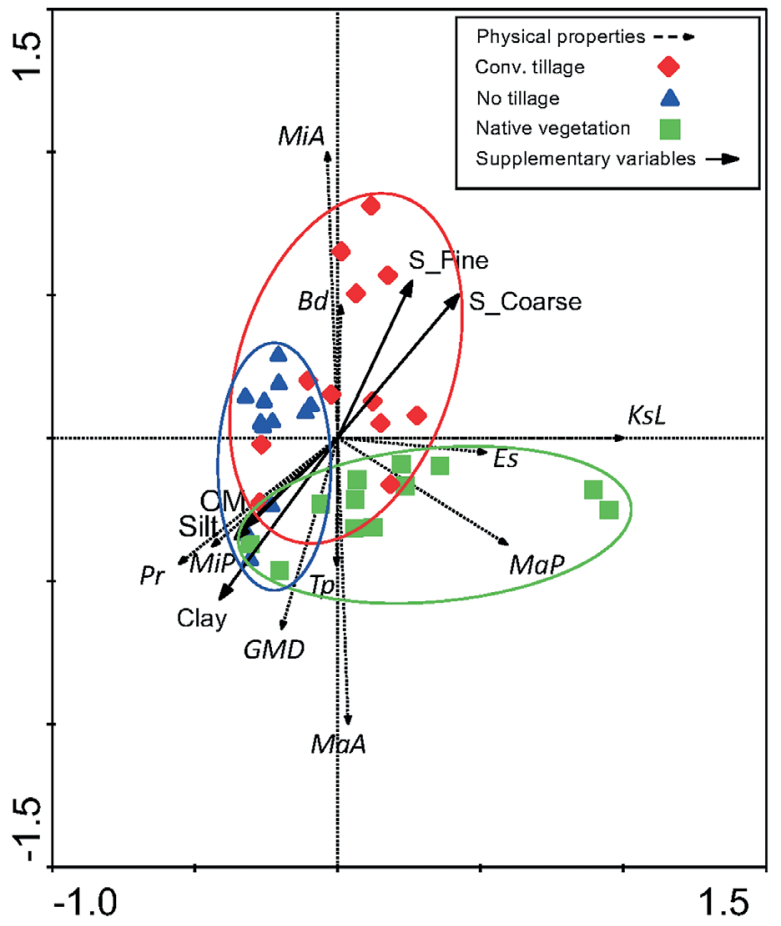

Figure 5 - Principal component analysis triplot with coordinates of soil physical properties, supplementary variables (clay, silt, fine sand, coarse sand and soil organic matter) and sampling points. $\mathrm{Bd}=$ bulk density, Es = effective saturation, $\mathrm{KsL}=$ hydraulic conductivity, $\mathrm{Pr}=$ penetration resistance, $\mathrm{Tp}=$ total porosity, $\mathrm{MaP}=$ macroporosity, $\mathrm{MiP}=$ microporosity, $\mathrm{MaA}=$ macroaggregates, $\mathrm{MiA}=$ microaggregates, $\mathrm{GMD}=$ geometric mean diameter.

physical quality compared to the native vegetation. The degree of impact is variable, and silt, clay and organic matter contents are key elements that determine resistance to penetration, total porosity and microporosity. No-tillage compared to conventional soil tillage shows higher bulk density, resistance to penetration and aggregation and lower total porosity, macroporosity and hydraulic conductivity.

\section{REFERENCES}

ANDREOTTI M, CARVALHO MP, MONTANARI R, BASSO FC, PARIZ CM, AZENHA MV AND VERCESE F. 2010. Produtividade da soja correlacionada com a porosidade e a densidade de um Latossolo Vermelho do cerrado brasileiro. Cienc Rural 40: 520-526.
ARAÚJO FS, SALVIANO AAC, LEITE LFC, SOUZA ZMD AND SOUSA ACMD. 2010. Physical quality of a yellow Latossol under integrated crop-livestock system. Rev Bras Ci Solo 34: 717-723.

ARSHAD MA, LOWERY B AND GROSSMAN B. 1996. Physical tests for monitoring soil quality. In: Doran JW and Jones AJ (Eds), Methods for assessing soil quality. Soil Sci So Am J, p. 123-141.

BARBOSA LR, NUNES LAPL, ARAÚJO ASF, SILVA FR AND IBIAPINA TVB. 2016. Penetration resistance and density of a Yellow Oxissol under conventional management at different ages. Biosci J 32: 115-122.

BERISSO FE, SCHJONNING P, KELLER T, LAMANDÉ M, ETANA A, JONGE LW, IVERSEN BV, ARVIDSSON J AND FORKMAN J. 2012. Persistent effects of subsoil compaction on pore size distribution and gas transport in a loamy soil. Soil Tillage Res 122: 42-51.

BERTOL I, ALBUQUERQUE JA, LEITE D, AMARAL AJ AND ZOLDAN JUNIOR WA. 2004. Propriedades físicas do solo sob preparo convencional e semeadura direta em rotação e sucessão de culturas comparadas as do campo nativo. Rev Bras Ci Solo 28: 155-163.

BEUTLER NA, MURANETO JD, RAMÃO CJ, GALON L, DIAS NP, POZZEBON BC, RODRIGUES LAT, MURANETO GS, GIACOMELI R AND RAMOS PV. 2012. Propriedades físicas do solo e produtividade de arroz irrigado em diferentes sistemas de manejo. Rev Bras Ci Solo 36: 1601-1607.

BILIBIO WD, CORRÊA GF AND BORGES EM. 2010. Atributos físicos e químicos de um Latossolo, sob diferentes sistemas de cultivo. Cienc Agrotec 34: 817-822.

BORGHI E, AVANZI JC, BORTOLON L, LUCHIARI JUNIOR A AND BORTOLON ESO. 2016. Adoption and use of precision agriculture in Brazil: Perception of growers and service dealership. J Agr Sci 8: 89-104.

BORTOLUZZI EC, SILVA VR, PETRY C AND CECCHETTI D. 2008. Porosidade e retenção de água em um Argissolo sob manejo convencional e direto submetido a compressões unidimensionais. Rev Bras Ci Solo 32: 1447-1457.

CASTRO FILHO C, MUZILLI O AND PODANOSCHI AL. 1998. Estabilidade dos agregados e sua relação com o teor de carbono orgânico num Latossolo Roxo Distrófico, em função de sistemas de plantio, rotações de culturas e métodos de preparo das amostras. Rev Bras Ci Solo 22: 527-538.

CASTRO OM, VIEIRA SR AND SIQUEIRA GM. 2010. Atributos físico-hídricos de um Latossolo Vermelho eutroférrico sob diferentes sistemas de manejo. Bragantia 69: 433-443.

CHAMEN WCT, MOXEY AP, TOWERS W, BALANAB AND HALLETT PD. 2015. Mitigating arable soil compaction: a reviewand analysis of available cost and benefit data. Soil Tillage Res 146: 10-25. 
CLAESSEN MEC. 1997. Manual de métodos de análise de solo. $2^{\text {a }}$ ed., Rio de Janeiro: Embrapa, 212 p.

CONAB - COMPANHIA NACIONAL DE ABASTECIMENTO. 2016. Acompanhamento da safra brasileira de cana-de-açúcar 2016/17. Disponível em http://www.conab.gov.br/. Acesso em 24 de Julho de 2016.

CORBEELS M, MARCHÃO RL, SIQUEIRA NETO M, FERREIRA EG, MADARI BE, SCOPEL E AND BRITO OR. 2016. Evidence of limited carbonsequestration in soils under no-tillage systems in the Cerrado of Brazil. Sci Rep 6: $1-8$.

CORTEZ JC, ALVEZ ADS, MOURA MRD, OLSZEVSKI N AND NAGAHAMA HJ. 2011. Atributos físicos do Argissolo Amarelo do semiárido nordestino sob sistemas de preparo. Rev Bras Ci Solo 35: 1207-1216.

COSTA JUNIOR C, PICCOLO MC, SIQUEIRA NETO M, CAMARGO PB, CERRI CC AND BERNOUX M. 2011. Carbono total e $\mathrm{C}^{13}$ em agregados do solo sob vegetação nativa e pastagem no Bioma Cerrado. Rev Bras Ci Solo 35: 1241-1252.

DONAGEMMA GK, CAMPOS DVB, CALDERANO SB, TEIXEIRA WG AND VIANA JHM. 2011. Manual de métodos de análise de solo. $2^{\mathrm{a}}$ ed., Rio de Janeiro: Embrapa, 230 p.

DONAGEMMA GK ET AL. 2016. Characterization, agricultural potential, and perspectives for the management of light soils in Brazil. Pesq Agropec Bras 51: 1003-1020.

DRESCHER MS, REINERT DJ, DENARDIN JE, GUBIANI PI, FAGANELLO A AND DRESCHER GL. 2016. Duração das alterações em propriedades físico-hídricas de Latossolo argiloso decorrente da escarificação mecânica. Pesq Agropec Bras 51: 159-168.

FIGUEIREDO CC, RAMOS MLG AND TOSTES R. 2008. Propriedades físicas e matéria orgânica de um Latossolo Vermelho sob sistemas de manejo e Cerrado nativo. Biosci J 24: 24-30.

FONTENELE W, SALVIANO AAC AND MOUSINHO FEP. 2009. Atributos físicos de um Latossolo Amarelo sob sistemas de manejo no cerrado piauiense. Rev Cienc Agron 40: 194-202.

FREITAS JÚNIOR E AND SILVA EM. 1984. Uso da centrífuga para a determinação da curva de retenção de água do solo, em uma única operação. Pesq Agropec Bras 19: $1423-1428$.

ISLAM R AND REEDER R. 2014. No-till and conservation agriculture in the United States: An example from the David Brandt farm, Carroll, Ohio. Int Soil Water Cons Res 2: 97-107.

KAMIMURA KM, ALVES MC, ARF O AND BINOTTI FFS. 2009. Propriedades físicas de um Latossolo Vermelho sob cultivo do arroz de terras altas em diferentes manejos do solo e da água. Bragantia 68: 723-731.
LLANILLO RF, RICHART A, TAVARES FILHO J, GUIMARÃES MF AND FERREIRA RRM. 2006. Evolução de propriedades físicas do solo em função dos sistemas de manejo em culturas anuais. Semin Cienc Agrar 27: 205-220.

MAPA - MINISTÉRIO DA AGRICULTURA, PECUÁRIA E ABASTECIMENTO. 2012. Plano Setorial de Mitigação e de Adaptação às Mudanças Climáticas para a Consolidação de uma Economia de Baixa Emissão de Carbono na Agricultura. Plano ABC (Agricultura de Baixa Emissão de Carbono). Brasília: Ministério da Agricultura, Pecuária e Abastecimento, Ministério do Desenvolvimento Agrário, $173 \mathrm{p}$.

MARCHÃO RL, BALBINO LC, SILVA EM, SANTOS JUNIOR JDG, SÁ MAC, VILELA L AND BECQUER T. 2007. Qualidade física de um Latossolo Vermelho sob sistemas de integração lavoura-pecuária no cerrado. Pesq Agropec Bras 42: 873-882.

MARCHÃO RL, BECQUER T, BRUNET D, BALBINO L, VILELA L AND BROSSARD M. 2008. Carbon and nitrogen stocks in a Brazilian clayey Oxisol: 13 years effects of integrated crop livestock management systems. Soil Tillage Res 43: 115-122.

MARCOLAN AL AND ANGHINONI I. 2006. Atributos físicos de um Argissolo e rendimento de culturas de acordo com o revolvimento do solo em plantio direto. Rev Bras Ci Solo 30: 163-170.

PANACHUKI E, BERTOL I, ALVES SOBRINHO T, OLIVEIRA PTS AND RODRIGUES DBB. 2011. Perdas de solo e de água e infiltração de água em Latossolo Vermelho sob diferentes sistemas de manejo. Rev Bras Ci Solo 35: 1777-1785.

PRAGANA RB, RIBEIRO MR, NÓBREGA JCA, RIBEIRO FILHO MR AND COSTA JA. 2012. Qualidade física de Latossolos Amarelos sob plantio direto na região do Cerrado Piauiense. Rev Bras Ci Solo 36: 1591-1600.

ROGOWSKI AS. 1971. Watershed physics: model of soil characteristics. Water Resour Res 7: 1575-1582.

SÁ MAC, SANTOS JUNIOR JDG, FRANZ CAB AND REIN TA. 2016. Qualidade física do solo e produtividade da cana-de-açúcar com o uso da escarificação entre linhas de plantio. Pesq Agropec Bras 51: 1610-1622.

SANTOS DP, SANTOS GG, SANTOS IL, SCHOSSLER TR, NIVA CC AND MARCHÃO RL. 2016. Caracterização da macrofauna edáfica em sistemas de produção de grãos no Sudoeste do Piauí. Pesq Agropec Bras 51: 1466-1475.

SANTOS GG, MARCHÃO RL, SILVA EM, SILVEIRA PM AND BECQUER T. 2011. Qualidade física do solo sob sistemas de integração lavoura-pecuária. Pesq Agropec Bras 46: 1339-1348.

SANTOS HG, JACOMINE PKT, ANJOS LHC, OLIVEIRA VA, OLIVEIRA JB, COELHO MR, LUMBRERAS JF AND CUNHA TJF. 2013. Sistema brasileiro de 
classificação de solos. $3^{\mathrm{a}}$ ed., Rio de Janeiro: Embrapa Solos, $353 \mathrm{p}$.

SENA KN, MALTONI KL, FARIA GA AND CASSIOLATO AMR. 2017. Organic Carbon and Physical Properties in Sandy Soil after Conversion from Degraded Pasture to Eucalyptus in the Brazilian Cerrado. Rev Bras Cienc Solo 41: 1-15.

SILVA EM AND AZEVEDO JA. 2002. Influência do período de centrifugação na curva de retenção de água em solos de Cerrado. Pesq Agropec Bras 37: 1487-1494.

SILVA MAS, MAFRA AL, ALBUQUERQUE JA, BAYER C AND MIELNICZUK J. 2005. Atributos físicos do solo relacionados ao armazenamento de água em um Argissolo Vermelho sob diferentes sistemas de preparo. Cienc Rural 35: 544-552.

SILVA RL, MATIAS SSR, LOBATO MGR AND NÓBREGA JCA. 2014. Atributos físicos do solo em diferentes coberturas vegetais na região do Piauí. Rev Caatinga 27: 160-168.

SOIL SURVEY STAFF. 1993. Soil Conservation Service. $1^{\text {st }}$ ed., Washington: United States Department of Agriculture, $437 \mathrm{p}$.

SORACCO CG, LOZANO LA, BALBUENAI R, RESSIA JM AND FILGUEIRA RR. 2012. Contribution of macroporosity to water flux of a soil under different tillage systems. Rev Bras Cienc Solo 36: 1149-1155.

SOUZA GS, SOUZA ZM, COOPER M AND TORMENA CA. 2015. Controlled traffic and soil physical quality of an Oxisol under sugarcane cultivation. Sci Agric 72: 270-277.

STOLF R. 1991. Teoria e teste experimental de fórmulas de transformação dos dados de penetrômetro de impacto em resistência do solo. Rev Bras Cienc Solo 15: 229-235.
STONE LF, GUIMARÃES CM AND MOREIRA JAA. 2002. Compactação do solo na cultura do feijoeiro - I: efeitos nas propriedades físico-hídricas do solo. Rev Bras Eng Agric Ambient 6: 207-212.

TAVARES FILHO J, BARBOSA GMC, GUIMARÃES MF AND FONSECA ICB. 2001. Resistência do solo à penetração e desenvolvimento do sistema radicular do milho (Zea mays) sob diferentes sistemas de manejo em um Latossolo Roxo. Rev Bras Cienc Solo 25: 725-730.

TORMENA CA, BARBOSA MC, COSTA ACS AND GONÇALVES ACA. 2002. Densidade, porosidade e resistência à penetração em Latossolo cultivado sob diferentes sistemas de preparo do solo. Sci Agric 59: 795801.

TORMENA CA, SILVA AP AND LIBARDI PL. 1998. Caracterização do intervalo hídrico ótimo de um Latossolo Roxo sob plantio direto. Rev Bras Cienc Solo 22: 573-581.

VICENTE TFS, PEDROSA EMR, ROLIM MM, OLIVEIRA VS, OLIVEIRA AKS AND SOUZA AMPL. 2012. Relação de atributos do solo e estabilidade de agregados em canaviais com e sem vinhaça. Rev Bras Eng Agric Ambient 16: 1215-1222.

WRB - WORLD REFERENCE BASE FOR SOIL RESOURCES. 2015. International soil classification system for naming soils and creating legends for soil maps. Food and Agriculture Organization of the United Nations. Rome: IUSS/ISRIC/FAO, World Soil Resources Reports, $203 \mathrm{p}$.

YODER RE. 1936. A direct method of aggregate analysis of soil and a study of the physical nature erosion losses. J Amer Soc Agron 28: 337-351. 